\title{
PLANNED BEHAVIOR THEORY IN PAYING CASH WAQF
}

\author{
Purnama Putra $^{\left.a^{*}\right)}$, Isfandayani ${ }^{a)}$ \\ ${ }^{a)}$ Universitas Islam 45, Bekasi, Indonesia \\ ${ }^{*}$ Corresponding Author: purnama.p41@gmail.com
}

Article history: received 10 December 2019; revised 29 December 2019; accepted 06 February 2020

\begin{abstract}
The potential of Waqf in Indonesia which is in the movement of followers of the largest Muslim religion in the World that is equal to $85 \%$ since the days of Pre-Independence. The legal order in Indonesia that underlies the management of waqf is very complete than Zakat, Infaq or Alms. This completeness is manifested in Law No. 41/2004 concerning Endowments and Government Regulation No. 42/2006 concerning Implementation of Law No. 41/2004. Both legality in the form of regulations and the Law provide a more certain legal basis for increasing public trust and guarantee of waqf assets. It became the starting point for the management of waqf and the collection of waqf funds in Indonesia. This study uses a quantitative method design in identifying what factors influence people's intentions in carrying out cash waqf. Data collection is done through filling out the questionnaire then be processed the validity and reliability test of 50 people and then given to a sample of 200 people. Factors affecting the intention to fulfill cash waqf based on this research are Attitude, Subjective Norms and Behavioral Control. Third, the Attitude, Subjective Norm, and Behavioral Control variables together have a significant influence on the variables of waqf intentions on cash waqf. Attitude variable towards cash Intention variable is $4.62 \%$, Subjective Norm variable is $2.88 \%$, Behavioural Control variable is $8.5 \%$. Therefore, it can be concluded that the most dominant effective contribution value influencing cash intention variable is the Behavioral Control variable that is $8.5 \%$.
\end{abstract}

Keywords: cash WAQF: planned behavior: intention.

\section{INTRODUCTION}

Waqf as one of the legal actions, in the context of regulation in Indonesia, has actually long since been institutionalized and practiced in people's lives. It is estimated that this waqf institution has existed since Islam entered the archipelago, then developed along with and in line with the development of Islam in Indonesia. The development of waqf in the early days was not yet supported by formal regulations governing it as in the laws and regulations, the practice of representation as long as it was only guided by traditional fiqh books compiled several centuries ago, of course many things were inadequate. [1]

The dynamics of waqf issues emerge in the history of Indonesian representation with the accompanying sociopolitical conditions. Law Number 41 of 2004 concerning Waqf is an awareness of Indonesian Muslims of the large potential of waqf and at the same time an effort to empower this great potential. Based on this law, Muslims make efforts to reform the endowment law. Emerging several important points of waqf that are even contrary to the practices and beliefs of the Muslim community so far. Judging from the government's involvement, the enactment of this Law shows that the government is quite serious in paying attention to the management and development of waqf in Indonesia. [2]

In the context of Indonesia, the endowment of money for Muslims is new. This can be observed with the birth of the fatwa of the Indonesian Ulema Council on the endowment of money which was established on May 11, 2002. The law on waqf itself was also just passed by the President on October 27, 2004. Law no. 41 of 2004 Article 42 stipulates that nadzir is obliged to manage and develop waqf property in accordance with its purpose, function and designation. To have maximum usability, nadzir must be trustworthy and professional. Without these two capabilities, a nadzir may not be able to manage endowment assets optimally.[3] Law No. 41 explains the change in the waqf paradigm that starts from the use of assets / physical to the management of the value of assets for development for productive earning functions which can benefit the welfare of the people.

As the world's largest Muslim nation, Indonesia has the potential to develop cash waqf. However, until now the potential of waqf as a means of doing good for the interests of the community has not been managed and maximally empowered within the national scope. In fact, the potential as a developing country with the largest Muslim population in the world, if properly regulated and developed, will have such a huge impact on society. If waqf in Indonesia can be handled well in its management, then undoubtedly the problems of society faced by our nation now and in the future will be easily overcome, because in the beginning the problems of society generally revolve around financial problems. [4]

The essence of Islamic economic processes is the effort of meeting what humans need based on Islamic values to achieve the aims of the religion. [5] Waqf from an economic point of view can be said as an instrument of saving as well as prosperity (prosperity), namely as a potential fund to be invested in productive assets that can provide results or income. This is what is said with the endowment of money combining saving and investment measures simultaneously. Waqf can also be treated as an investment that provides a return on investment that can be 
extracted to provide benefits to the community. From this perspective, waqf can be seen as a means of creating multiplier effects both in economic and social terms. By implementing waqf, it means sacrificing the opportunity for consumption today and simultaneously placing it as an investment that can increase the accumulation of social capital in the economy for the purpose of increasing social services and future income. Waqf money, is seen as one solution that can make waqf become more productive. Because money here is no longer used as a means of exchange, more than that is capital that is ready to be used as a means of production.

The potential of cash waqf in Indonesia is estimated to be quite large, namely the potential cash waqf that can be collected from 10 million Muslim residents is around Rp. 3 trillion per year.[6] Changes in the paradigm of waqf to be productive and the permissibility of cash / cash waqf makes the potential for waqf even greater then optimizing the collection of waqf funds becomes more attractive for further study so that waqf becomes an instrument of national welfare.

The concept of cash waqf developed in the last two decades is interesting to measure the effectiveness and efficiency of its work in building Islamic-based philanthropy in Indonesia[7], [8]. This study seeks to analyze public behavior in the performance of cash waqf by basing on the planned behavior theory (TPB) regarding the application of TPB in pay zakat[9]-[11] and regarding the factors that influence the entrepreneurial spirit of Postgraduate students.[12] The selection of the theory of Planned behavior is expected to be able to provide answers by identifying what are the factors and dominant factors that influence the intentions of the community to fulfil cash waqf. The expected outcomes of this study are able to provide input to stakeholders, especially waqf managers (Nadhir) following up by mapping which factors are prioritized to optimize cash waqf receipts.

The potential of Waqf in Indonesia which is in the movement of the largest Muslim followers in the World is 85\% attached since the Pre-Independence era. The legal order in Indonesia that underlies the management of waqf is very complete than Zakat, Infaq or Alms. This completeness is manifested in Law No. 41/2004 concerning Endowments and Government Regulation No. 42/2006 concerning Implementation of Law No. 41/2004. Both legality in the form of regulations and the Law provide a more certain legal basis for increasing public trust and guarantee of waqf assets. Cash Waqf legalized by Law Number 41 of 2004 became the starting point for the management of waqf and the collection of waqf funds in Indonesia. Waqf property can be used more productively because it contains understanding and management patterns of empowering more modern waqf potential according to the needs and conditions of the times. Based on these developments researchers are interested in analysing the factors that influence society in carrying out cash waqf using the Planned Behavior theory.

\section{RESEARCH METHODS}

This research was designed as a field study because there was no manipulation or treatment of the independent variables, but by taking measurements on the variables to be tested. The right method for this design is a survey with a measuring instrument using a questionnaire. In this design hypothesis testing is also carried out. [11]

The selection of respondents in this study was conducted by purposive sampling by considering the recommended waqf data / originating from Nadir in this case Global Waqf, Al-Azhar Caring for People, Rapid Action and BMT Individuals of Cendikia Amanah and other waqf management institutions respondents with the number of samples to be used as a validity and reliability test of 50 people. According to the purpose of the study, the data analysis that will be used is the multiregression analysis method (multiple regression analysis)[13]-[15]

\section{RESULTS AND DISCUSSION}

This research is the Questionnaire Trial stage as a research instrument and the data input process after the instrument validity and reliability test stage.

\section{Research Instrument Trial Phase}

The Trial Phase of the research instrument is the stage of collecting as many beliefs as possible attached to the subject. This stage is known as the Elitation stage carried out through directional interviews by giving freedom to the subject to provide information about beliefs related to waqf behavior to perform Cash Waqf.[9], [11] The questions raised in the interview are in the context of gathering beliefs related to the three determinants of the intention of the Waqf (the person who represents) in performing the Cash Waqf, namely:

1. Questions about attitude attitudes, in the form of questions: "What are the thoughts that have crossed Wakif's mind in the performance of cash waqf and what are the positive and the negative things conveyed in carrying out cash waqf?"

2. Questions about subjective norm beliefs, in the form of the question "Is there anyone who encourages and discourages you (family, leader or coworkers) to fulfill cash waqf?"

3. Questions about belief perceived behavioral control, in the form of questions: "What conditions might you encounter that encourage and discourage you from fulfilling cash waqf?"

After determining the minimum frequency limit of these questions, several questions that have the highest frequency are included in the questionnaire as research instruments. The research instrument included several questions from the attached elasticity stage. This research instrument was distributed to 50 respondents outside the sample data, to test the validity and reliability. [16] 


\section{Influence of Variable Attitudes, Subjective Norms, Behavioral Controls on Muzaki's Intention in Performing Cash Waqf}

The first question in this study is about how the influence of attitudes, subjective norms, and behavioral control on the intention of waqf in cash. To answer the research question, the data obtained from 200 respondents using a questionnaire instrument were analyzed using the multiple regression method.[13] This multiple regression analysis is assisted by using eviews software, to get the regression coefficient value, R2 value, Beta value, and significance value.

The results of multiple regression analysis are shown in table 1.

Table I

Regression Of Subjective Norms, Behavioral Control Variables Towards Cash Waqf Intention

\begin{tabular}{|l|c|c|c|c|c|}
\hline & B & S.E & Beta (W) & T & Sig. \\
\hline Constant & 2,64 & & & 1,869 & 0,063 \\
\hline Attitude & 0,082 & 0,0462 & 0,155 & 2,28 & 0,023 \\
\hline $\begin{array}{l}\text { Subjective } \\
\text { Norm }\end{array}$ & 0,092 & 0,0288 & 0,112 & 1,676 & 0,095 \\
\hline $\begin{array}{l}\text { Behavior } \\
\text { Control }\end{array}$ & 0,161 & 0,085 & 0,25 & 3,877 & $0.000^{*}$ \\
\hline $\begin{array}{l}\text { F Value Of } \\
\text { Model }\end{array}$ & 15,446 & & & & $0.000^{*}$ \\
\hline $\mathrm{R}^{2}$ & 0,16 & & & & \\
\hline Adjusted $\mathrm{R}^{2}$ & 0,15 & & & & \\
\hline
\end{tabular}

Table 1 shows that the attitudes, subjective norms, and behavioural control variables influence the intention to make a wakif cash representation. This can be seen from the adjusted R2 value of 0.160 and the statistical $F$ value of 15.446, and has a significance value of less than 0.05 which is equal to 0.000 . This result means that as much as $16 \%$ of the intention to represent waqf cash can be explained by the three independent variables namely attitudes, subjective norms, and behavioral control. Thus, the model can be applied to explain the intention to represent waqf cash.

So based on table 1 analysis, the intention pattern of waqf cash representation is as follows:

$$
\begin{aligned}
\mathrm{I}=2,640 & +0.082(\mathrm{AB})+0.092(\mathrm{SN})+0.161(\mathrm{PBC}) \\
\mathrm{I} & =\text { intention to behave } \\
\mathrm{AB} & =\text { Attitude towards behavior B } \\
\mathrm{SN} & =\text { Subjective Norms } \\
\mathrm{PBC} & =\text { Perceived Behavioral Control }
\end{aligned}
$$

This research suggests three hypotheses. To test this hypothesis, $t$ value is calculated. Then the calculated $t$ value is compared with the $t$ table value. If $t$ arithmetic $>\mathrm{T}$ table, the hypothesis is accepted. In addition to comparing the value of $t$ arithmetic with $t$ table, hypothesis testing can also be seen from the significance of the $t$ value. If the significance is less than 0.05 or $p<0.05$, then the alternative hypothesis is accepted, and if $\mathrm{p}>0.05$, then the initial hypothesis is accepted [11], [13]

\section{Hypothesis 1 is:}

H1: There is an influence between attitudes towards the intention of waqf in cash

Based on the results of the regression analysis in table 1 above, it appears that the significance value for the attitude variable towards the intention of having a waqf in cash is 0.023 . These results indicate that the value of $p<0.05$, which means the initial hypothesis is rejected while the alternative hypothesis is accepted.[13], [15] So that the attitude variable has an influence on the intention to represent waqif cash significantly.

Based on the description of research data Attitude variable, which has the highest average score is the respondents' beliefs about cash waqf can help others who are deficient and the lowest is property concerns will decrease if the respondent pays cash waqf, as well as the results of this hypothesis test. This has a significant attitude in influencing the intention of respondents as waqf in paying cash waqf. [17]-[19] These results also indicate that respondents in this study who are also waqif have attitudes that are in accordance with the Qur'an 'an and hadith. [18]

2. Hypothesis 2 is:

$\mathrm{H} 2$ : There is an influence between subjective norms on cash waqf intentions

In the results of the regression analysis in table 1 above, it appears that the significant value for the subjective norm variable to the intention to have a cash representation is 0.095 . These results indicate that a value of $p>0.05$, which means the initial hypothesis is accepted while the alternative hypothesis is rejected. So that the subjective norm variable has no effect on the intention to represent waqif cash significantly.

Based on the results of this hypothesis test shows that the respondents' answers tendency in this study regarding subjective norm variables that the role of parents is quite large in supporting respondents paying cash waqf does not significantly affect the intention of respondents' cash representation. This result also shows that the intention to cash in someone is determined by the individual himself and that this is the main factor for someone to make cash waqf payments not because they are supported and told by people around them, whether from parents, relatives, office friends, or from ustadz. [9]-[11]

3. Hypothesis 3 is:

H3: There is an influence between behavioural control on the intention of waqf with cash

Based on the significant value in table 1 above, it is seen that the significance value for the behavioural control variable on cash bearing intention is 0,000 . These results indicate that the value of $\mathrm{p}<0.05$, which means the initial hypothesis is rejected while alternative hypotheses are accepted.[14] So that the behavioural control variable has an influence on the intention to represent waqif cash significantly.

Based on respondents' answers regarding behavioural control previously described, it is known that the highest average score on the Behavioural Control variable is the respondent making cash waqf payments 
because paying cash waqf is one of the pillars of Islam that must be obeyed. The results of this study indicate the level of compliance of respondents in this study on the teachings of Islam in particular the implementation of Islamic pillars to pay cash waqf is large enough, so it can significantly influence the intense respondents in paying cash waqf. [18]

Other statements which are indicators of the Behavioral Control variable also have a significant influence on the intention to represent a cash waqf. The results of this study are not much different from the results of research conducted by Ida Husna Binti Hedzir entitled ,"Research Intention to Pay Zakah on Employment Income Among Manufacturing Employees In Penang.” This study examines the relationship between attitudes, subjective norms and behavioural control using the theory of planned behaviour. [9]

The results showed that the attitude and control of behaviour significantly influence the intention to pay cash waqf. While subjective norms do not significantly influence the intention to pay cash waqf. The results of this study also have two variables significantly influence the intention to represent waqf cash i.e. attitude and behaviour control variables. This study generally reveals that the theory of planned behavior can predict cash waqf intentions so that cash waqf institutions can be used to develop cash waqf education in order to increase cash waqf acceptance.[9], [10], [19], [20]

\section{The Effective Contribution of Attitudes, Subjective Norms, and Behavioural Control to the Cash-Flipped Representative Intent}

The second question raised in this study is how much the effective contribution of Attitude, Subjective Norms, and Behavioural Controls to Wise cash flow interventions. The Effective Contribution Value (SE) can be seen in table 1. In Table 1, it can be seen that the Effective Contribution (SE) value of the Attitude variable to the wakif cash Intensity variable is 0.0462 or $4.62 \%$. This result shows that the Attitude variable can only affect the $4.62 \%$ wacky cash flow Intent variable. This indicates that the other variables not considered in this study had a greater effective contribution to wakif cash-free Intentions.

While the effective contribution value for the Subjective Norm variable was 0.0288 or $2.88 \%$. The value of this effective contribution is smaller than the effective contribution of the Attitude variable to the wacky cash flow Intent. These results indicate that many other variables not addressed in this study have a greater effective contribution to wakif cash-based Intentions. Due to its small effective contribution, the influence of the Subjective Norms had a non-significant impact on wakif cash-free Intentions.

The Effective Contribution Value of the Behavioural Control Variable to the cash-based wakif Intensity was 0.085 or $8.5 \%$. The Effective Contribution Value of the Control Variable This behaviour is greater than the value of the effective contribution of the Subjective Attitudes and Norms variable to the wacky cash-flow Intent. To the extent that the influence of the Behavioural Control variables on the
Interval variable is cash flow. However the value of the Effective Contribution of Behavioural Control Variables to Wise Cash Flow Intervals is small, so many other variables not discussed in this study have greater effective contribution value to Wise Cash Flow Intensions.

The overall contribution of the variables Attitudes, Subjective Norms, and Behavioural Controls to wakif cashbased Intentions were found at the R2 value of the regression model in this study to be $16 \%$. These values indicate that the three variables Attitude, Subjective Norms, and Behavioural Control can only contribute to $16 \%$ of the wacky cash-flow Intent variables, while the remaining $84 \%$ is affected by other variables not covered in this study.

\section{The Most Dominant Effective Contribution Affects the Cash Intention Endowment Intention Variable}

The third question in this study is the most dominant effective contribution affecting the intention to variable cash waqf intention. To answer this question, it can be seen in table 1. Based on the results of the data analysis shown in table 1, it can be seen that the variable that has the greatest effective contribution value in influencing the intention variable in the form of cash waqf is the Behavioural Control variable. It can be seen that the effective contribution value of the Behavioural Control variable is 0.085 or $8.5 \%$ greater than the Attitude and Subjective Norms variable on the Intention variable with a wakif cash representation. In addition to having the largest contribution value, the Behavioural Control variable also has a significant influence on the intention variable in the form of cash waqf.

The results of this study are in accordance with the theory conveyed by Ajzen (Ajzen, 2005) through the theory of planned behaviour. Behavioural control factors strengthen or weaken intentions. If the behaviour is seen as possible, the intention strengthens. If the behaviour is considered difficult or impossible, the intention to recede. Likewise with the Behaviour Control in this study, if the respondents in this study who were waqf did not pay cash waqf because cash waqf was one of the financial instruments that became sharia in Islam, then the respondent would not immediately pay cash waqf this year, and the respondent will consider overpaying cash waqf payments, if the respondent's income does not increase[9]-[11]

While the results of this study indicate that the reason respondents pay cash waqf because cash waqf is one of Islamic sharia that must be obeyed in Islamic teachings has the highest average score compared to other statements related to the Full Behavior of respondents in paying cash waqf, so the statement items in Intention variable also has the highest average score, i.e. respondents will pay cash endowments assets this year are more priority than not adding spending for cash endowments because income does not increase.[17]-[19]

\section{CONCLUSION}

Factors affecting the intention to fulfill cash waqf based on this research are Attitude, Subjective Norms and 
Behavioral Control. Third, the variables of Attitude, Subjective Norms, and Full Behavior Control together have a significant influence on the variables of the endowment intention to fulfill cash waqf. Attitude variable towards cash intention variable is $4.62 \%$, Subjective Norm variable is $2.88 \%$, Behavioral Control variable is $8.5 \%$. Therefore, it can be concluded that the most dominant effective contribution value influencing cash intention variable is the Behavioral Control variable that is $8.5 \%$.

\section{REFERENCES}

[1] Khairuddin, 2014. Pergeseran paradigma pengaturan wakaf dalam perspektif hukum progresif, Al-'Adalah, vol. 12 , no. 1 , pp. $135-154$.

[2] W. Hermawan, 2014. Politik Hukum Wakaf di Indonesia Ta'lim J. Pendidik. Agama Islam, vol. 12, no. 2, pp. 147-161.

[3] M. Huda, 2012. Wakaf Dan Kemandirian Pesantren Dari Tebuireng Hingga Gontor," Islamica, vol. 7, no. 1, pp. 211-231.

[4] A. Atabik, 2014. Manajemen Pengelolaan Wakaf Tunai Di Indonesia. Ziswaf, vol. 1, no. 1, p. 2014.

[5] P. Putra and T. Sawarjuwono, 2019. Traditional Market Merchant Attitudes in the Perspective of Islamic Business Ethics. Opción, vol. 35, no. 20, pp. 1471-1487.

[6] M. E. Nasution and U. Hasanah, 2015. Wakaf Uang Inovasi Finansial Islam, Peluang dan Tantangan dalam Mewujudkan Kesejahteraan Umat, Jakarta.

[7] M. Fanani, 2011. Pengelolaan Wakaf Tunai Walisongo, vol. 19, no. 1, pp. 179-196.

[8] M. H. Ubaidillah, 2012. Manfaat Wakaf Tunai dalam Pembangunan Ekonomi Umat. El-Qist, vol. 02, no. 02, pp. 311-336.

[9] N. Huda, N. Rini, Y. Mardoni, and P. Putra. 2012. The Analysis of Attitudes, Subjective Norms, and Behavioral Control on Muzakki's Intention to Pay Zakah. Int. J. Bus. Soc. Sci., vol. 3, no. 22, pp. 271$279 .$.

[10] N. Huda, N. Rini, D. Anggraini, P. Putra, and Y. Mardoni, 2014. Pengaruh Sikap , Norma Subjektif Dan Kendali Prilaku Terhadap Intensi. J. Manaj., vol. 1, no. 2, pp. 60-74.

[11] P. Putra, 2016. Analisis Faktor-Faktor yang Mempengarugi Intensi Muzaki Membayar Zakat: Sebuah Survey pada Masyarakat Kota Bekasi," Maslahah, vol. 7, no. 1, pp. 99-109.

[12] S. P. Prabandari and P. I. Sholihah, 2014. The Influence of Theory of Planned Behavior and Entrepreneurship Education Towards Entrepreneurial Intention," J. Econ. Business, Account. Ventur., vol. 17, no. 3, pp. 385-392.

[13] I. G. Pernanu and P. Putra, 2016. Pengaruh Motivasi dan Kepuasan Kerja terhadap Kualitas Pelayanan: Survey pada Karyawan BTN Kantor Cabang Syariah Kota Bekasi," Maslahah, vol. 7, no. 2, pp. 15-32,.

[14] P. Putra, 2016. Pengaruh Pembiayaan Mudharabah, Musyarakah, Murabahah, Dan Ijarah Terhadap Profitabilitas 4 Bank Umum Syariah Periode 20132016. J. Organ. dan Manaj., vol. 14, no. 10, pp. 140150.

[15] Sugiyono, 2013. Metode Penelitian Kuantitatif Kualitatif dan $R \& D$. Bandung: Alfabeta.

[16] N. Rini, N. Huda, Y. Mardoni, and P. Putra. 2012. Peran Dana Zakat Dalam Mengurangi Ketimpangan Ekuitas J. Ekon. dan Keuang., vol. 17, no. 1, pp. 108127,.

[17] A. A. Al-Hadi, 2010. Hukum Perwakafan Islam dan Di Indonesia, 1st ed. Pena Salsabila,.

[18] A. F. Haq, 2017. Hukum Perwakafan di Indonesia, 1st ed. Depok: Raja Grafindo Persada.

[19] N. Nuwairah, 2009. Pemberdayaan Ekonomi Umat Melalui Wakaf." J. Kaji. Islam, vol. 1, no. 1,.

[20] P. Putra, S. A. Maharani, and D. V. Sara, 2018. Optimalisasi Wakaf dalam Sektor Pendidikan," Maslahah, vol. 9, no. 1, pp. 103-112,. 